\title{
Fate and Expression of Simian Virus 40 DNA after Introduction into Murine Cells under Nonselective Conditions
}

\author{
WILLIAM W. BROCKMAN, ${ }^{*}+$ JOAN B. CHRISTENSEN, ${ }^{*}$ KEVIN W. RYAN,,$\cdot 1$ \\ MARK SOUWAIDANE, ${ }^{*}$ AND MICHAEL J. IMPERIALE*, ${ }^{* 2}$ \\ *Department of Microbiology and Immunology and tGraduate Program in Cellular and Molecular Biology, University of Michigan Medical \\ School, Ann Arbor, Michigan 48109-0620
}

Received November 3, 1986; accepted January 20, 1987

\begin{abstract}
When SV40 infects mouse cells, it does not replicate but instead causes neoplastic transformation of a small percentage of the cells. It is unknown, however, what happens to the virus in those cells that do not become transformed. We introduced SV40 into mouse cells by nonselective means, either by cotransfection of SV40 DNA with a selectable marker or by random cloning of SV40-infected cells. We analyzed the fate of viral DNA sequences, expression of T antigens, and transformation properties of these cells. We found that, upon infection, viral DNA integration occurs at a frequency that is at least 10 -fold higher than the frequency of transformation. The majority of these cells are not transformed due to lack of expression of $T$ antigen. One cell line which expresses a truncated T antigen is not transformed. We have mapped the viral sequences in the genome of these cells and find that integration in the large $T$ intron is probably responsible for the defect. Lack of transformation can therefore be attributed to both cellular and viral factors, namely, introduction of viral DNA into cells that are resistant to transformation or integration of viral DNA in such a way that T antigen expression is prohibited. 1987 Academic Press, Inc.
\end{abstract}

\section{INTRODUCTION}

Cellular transformation of mammalian cells by SV 40 is dependent upon integration of viral DNA into the host genome and expression of the viral early transcription unit (Topp et al., 1981). To date, the organization of integrated SV40 DNA sequences and the effects of their expression on cellular growth properties have been examined mainly in cells selected for expression of the transformed phenotype or in revertants derived from such cells (Renger and Basilico 1972, 1973; Steinberg et al., 1978; Botchan et al., 1980; Ketner and Kelly, 1980). While integration of the SV40 genome is required for stable transformation, it is not known to what extent integration occurs without the appearance of the transformed phenotype. Analysis of cells containing SV40 DNA but failing to express the transformed phenotype should yield information regarding cellular factors affecting the expression of integrated viral genes. For example, one anticipates the existence of cells which can express functional $T$ antigens yet are not transformable due to alterations of cellular gene products required for virally induced transformation. It would be useful, therefore, to identify cells containing integrated SV40 DNA without selecting for the transformed phenotype.

In this communication we describe two approaches to the isolation of cells which contain SV4O sequences

\footnotetext{
1 Present address: Laboratory of Infectious Diseases, NIAID, Bethesda, MD 20892.

${ }^{2}$ To whom requests for reprints should be addressed.
}

but which have not been selected for the acquisition of the transformed phenotype. One approach has been to introduce SV40 into thymidine kinase-negative (tk-) 3T3 cells via cotransfection with the herpesvirus tk gene. These cells were assayed for the presence of viral DNA, expression of large $T$ and small $t$ antigens, and their transformation phenotype. We find that these cells exhibit a wide range of growth regulation. The second approach utilizes Southern blots to detect the presence of $S V 40$ sequences in BALB/C-3T3 cells that have been cloned under completely nonselective conditions after infection with SV4O virions. In this way, we have isolated cells that have acquired SV40 sequences without always undergoing alterations in cell growth. These cryptic transformants arise with a higher frequency than do overtly transformed cells. Characterization of one of the cryptic transformants reveals that it contains a single insertion of SV4O DNA that does not encompass an intact early region. This insert encodes the $19 \mathrm{~K}$ small $\mathrm{t}$ antigen and a truncated $33 \mathrm{~K}$ large $T$ antigen. The presence of small $t$ and the $N$ terminal portion of large $T$ are therefore not sufficient to produce the transformed phenotype.

\section{MATERIALS AND METHODS}

\section{Cells and virus}

All mammalian cells were grown at $33^{\circ}$ in $5 \% \mathrm{CO}_{2}$ in MEM supplemented with $10 \%$ FCS. B2-1 cells are a tk - line of 3T3 cells and were the gift of Dr. A. Boyd. SV40 strain 776 was used in these studies. 


\section{Transfections}

Cotransfection of SV40 DNA and the plasmid pTK $\times 1$, containing the HSV-1 gene (Enquist et al., 1979; gift of Dr. G. Scangos), and HAT selection were carried out as previously described (Littlefield, 1964; Ryan et al., 1985). Each $60-\mathrm{mm}$ dish was transfected with $20 \mu \mathrm{g}$ pTK $\times 1$ plus $5 \mu \mathrm{g}$ SV40 DNA.

\section{Transformation and immunological assays}

The procedure for 3 T3 cell overgrowth and soft agar assays has been reported (Brockman, 1978). Immunofluorescence and immunoprecipitation assays have also been described previously (Christensen and Brockman, 1982).

\section{Southern blots}

Genomic blots were performed by the method of Southern (1975), using nick-translated plasmid probes (Ribgy et al., 1977) or probes labeled by the random oligonucleotide priming method (Feinberg and Vogelstein, 1984). The plasmid pSVB3 has a complete copy of the SV40 genome, cut at the BamHI site, cloned into the $\mathrm{BamHI}$ site of $\mathrm{pBR} 322$. The amount of $\mathrm{pSVB} 3$ run in each lane is the equivalent of a single copy gene.

\section{Preparation of low molecular weight DNA}

Extraction of low-molecular-weight DNA was performed as described by Hirt (1967).

\section{RESULTS}

\section{Introduction of SV40 DNA into cells by} cotransfection with tk

To introduce large $T$ antigen into cells without selecting for its expression (e.g., transformation), we cotransfected SV40 DNA with $\mathrm{pTK} \times 1$, a plasmid containing the HSV- 1 tk gene, into B2-1 cells, a tk- line of $3 T 3$ fibroblasts. Cells expressing the tk gene were selected in HAT medium, and 72 HAT-resistant colonies were picked and grown up. Southern blot analysis revealed that 64 of these lines contained some SV 40 sequences. We examined each of these cell lines for the presence of $T$ antigen by immunofluorescent staining with a polyclonal anti-T serum and found that 57 of the lines were $T$ antigen positive by this criterion. Twenty-three of the lines contained both a $94 \mathrm{~K}$ large $T$ and a $17 \mathrm{~K}$ small $t$ antigen as judged by immunoprecipitation of $\left[{ }^{35}\right.$ S]methionine-labeled proteins (K.W.R., Ph.D. thesis, University of Michigan). Each of these lines was screened for its growth properties by assaying the ability to overgrow preformed $3 \mathrm{~T} 3$ cell monolayers and, for some of the clones, the ability to form anchorage- independent colonies in semisolid medium. These cells showed a wide range of growth characteristics, from fully transformed to marginally transformed (Fig. 1 and Table 1). One of these lines, A27, behaved just like its parent B2-1 in both growth assays. A complete characterization of the A27 line, which is resistant to SV40 transformation, has been reported (Ryan et al., 1985).

\section{Random isolation of cells containing SV40 DNA}

We were not able to use these data to ascertain the frequency with which SV40 integrates into the cellular chromosome since the cotransfection protocol used to generate these cell lines skews the analysis such that most $t k+$ lines were likely to also have received SV40 DNA (Perucho et al., 1980). To obtain a better quantitation of this frequency, we decided to clone SV40-infected cells without any selection for uptake of SV40 DNA. Our strategy was to screen the DNA from randomly cloned infected cells by Southern blot hybridization. As there is no selection such screening would seem to present a formidable task, even if the frequency of integration were several orders of magnitude greater than the frequency of overt transformation. It was essential, therefore, to infect cells under conditions such that as large a percentage of the cells as possible was overtly transformed. For this reason, the frequency of transformation of BALB/C-3T3 cells was assessed as a function of virus input. Overt transformation was assayed as the ability of infected cells to grow when suspended in semisolid medium (Fig. 2). At multiplications of infection below 4800 PFU per cell,
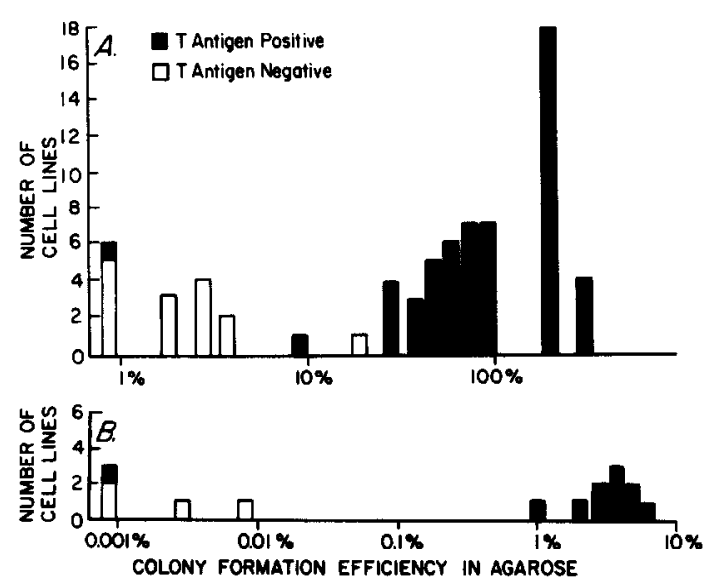

FiG. 1. Growth phenotypes of cells isolated from cotransfection of $\mathrm{SV} 40+\mathrm{tk}$. Cells were transfected as described under Materials and Methods. (A) The normalized plating efficiency of each cell line on 3T3 monolayers [(efficiency on monolayers/efficiency on plastic) $\times 100$ ] is plotted vs the number of lines with that efficiency. Total number of lines tested $=71$. (B) The efficiency of forming colonies in soft agar is plotted vs the number of lines with that efficiency. Total number of lines tested $=15$. 
TABLE 1

Growth Phenotypes of Indirectly Selected Cells

\begin{tabular}{|c|c|c|c|c|c|c|c|c|}
\hline $\begin{array}{l}\text { Soft agar } \\
\text { 3T3 }\end{array}$ & \multicolumn{2}{|c|}{+} & \multicolumn{2}{|c|}{+} & \multicolumn{2}{|c|}{-} & \multicolumn{2}{|c|}{ - } \\
\hline overgrowth & \multicolumn{2}{|c|}{+} & \multicolumn{2}{|c|}{-} & \multicolumn{2}{|c|}{+} & \multicolumn{2}{|c|}{-} \\
\hline T antigen & + & - & + & - & + & - & + & - \\
\hline & 13 & 0 & 0 & 0 & 4 & 1 & 1 & $14^{\circ}$ \\
\hline
\end{tabular}

Note. Total number of lines tested in both assays $=33$.

${ }^{\circ}$ One of these lines expressed small $t$ antigen

transformation increased with respect to m.o.i. in a linear fashion. The frequency of overt transformation in this region of the dose-response curve is approximately $3 \times 10^{5}$ PFU per transforming unit, which is comparable to the frequency of $10^{5} \mathrm{PFU}$ per transforming unit we have previously reported (Brockman, 1978). For the present analysis of the frequency of integration, therefore, we used an m.o.i. of 4800 , at which approximately $1 \%$ of the cells acquire the ability to grow in soft agar. Under such conditions, then, a minimum of 1 cell clone in 100 should contain SV40 sequences.

Cells were infected and cloned by endpoint dilution $24 \mathrm{hr}$ postinfection without selecting for the transformed phenotype. Twenty-three individual clones were propagated for 1 month (approx 26 generations) and then analyzed for the presence of SV40 DNA. Cellular DNA was examined by Southern blot assay after digestion with various restriction enzymes. A representative blot of Taql-digested DNA is shown in Fig. 3. The Taql digests of three of the clones, $\mathrm{C} 12$ and $\mathrm{C} 16$ (Fig. 3) and $\mathrm{C} 24$ (data not shown), yielded a single SV40-specific fragment which migrates at or near the position of full-length linear SV40. As Taql cuts SV40 at a single site, this could result from digestion of viral DNA that has not integrated or that has integrated in a tandem fashion. The DNA from three clones, C9 (Fig. 3) and C6 and C21 (data not shown), yielded SV40-specific Taql fragments which have mobilities different from those of linear SV40 genomes, indicating the probable

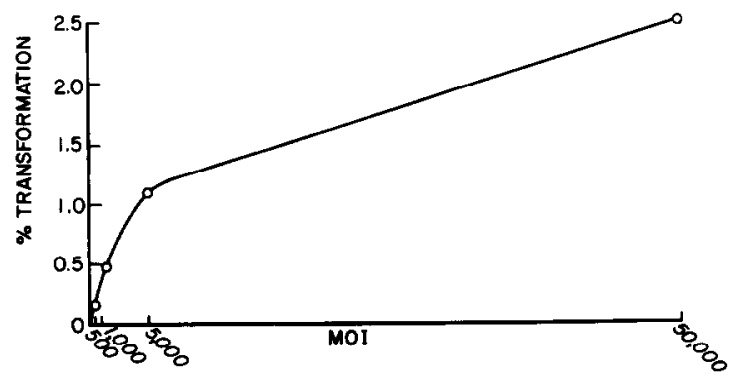

Fig. 2. Overt transformation frequencies at different multiplicities of infection. Transformation was assayed as described (Brockman, 1978).

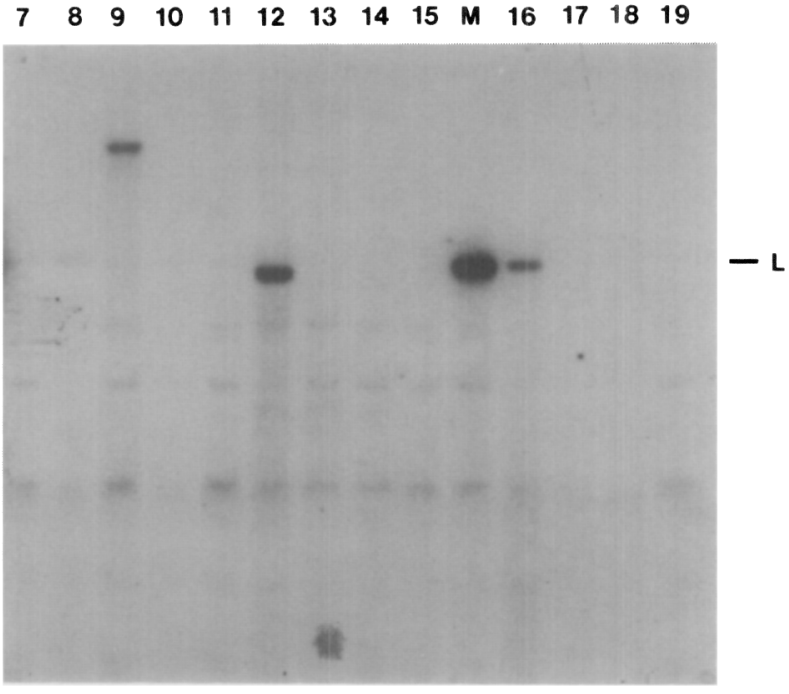

FIG. 3. Taql digests of DNA from randomly cloned SV40 infected cells. Genomic DNA $(30 \mu \mathrm{g})$ was digested, run on an agarose gel, blotted to nitrocellulose, and probed with pSVB3. Results are shown for clones $\mathrm{C} 7-\mathrm{C} 19$. Lane marked $M$ indicates a reconstruction in which linearized SV40 viral DNA (approximately a single copy's equivalent) was mixed with $30 \mu \mathrm{g}$ DNA from normal BALB/c-3T3 cells. $L$ indicates the position of this linear SV 40.

integration of SV40 sequences. The 23 clones were assayed at this time for the presence of SV40 T antigens by immunofluorescence. Only one clone, C6, expressed $T$ antigen detectable by this assay. At the same time that the cells were randomly cloned ( 1 day postinfection), an aliquot of the cells was plated in soft agar to determine the frequency of overt transformation. In contrast to the frequency of $6 / 23$ cells $(26 \%)$ containing SV 40 DNA, only $1.2 \%$ of the infected cells were overtly tranformed.

\section{Stability of viral DNA in infected cells}

The acquisition of SV40 sequences after infection, then, occurred at a frequency which is approximately an order of magnitude higher than the frequency of overt tranformation. The analysis of Taql-digested cellular DNAs suggests that the viral DNA present in three of the lines is integrated into the cellular genome while the viral DNA in the other three lines could be integrated or free. We performed further Southern blot analysis on the lines, particularly to obtain a more definitive determination of the state of viral DNA in lines $C 12, C 16$, and $\mathrm{C} 24$. Genomic DNA was digested with Bg/ll, which does not cut within SV40, or BgIl, which cuts SV40 once. Figure 4 shows the results of this experiment. Viral DNA could no longer be detected in four of the cell lines (C9, C16, C21, and C24). It was therefore not possible to determine whether the SV4O sequences in $\mathrm{C} 16$ and $\mathrm{C} 24$ had been present as integrated or free 


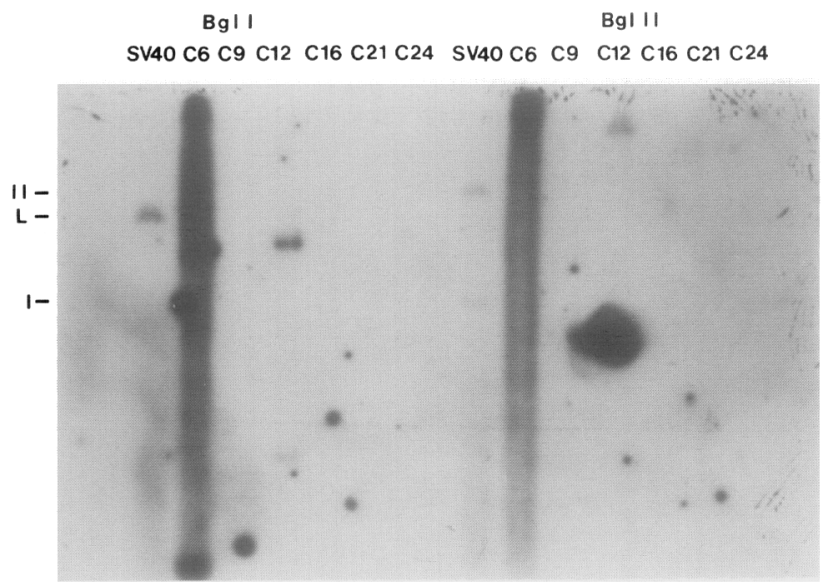

FIG. 4. Bg/l and $B g / l l$ digests were performed as described in Fig. 3. I and II indicate position of form I and II SV40 DNA, respectively. $\mathrm{L}$ indicates position of linear SV40.

DNA. In contrast, SV40 DNA could be detected in clones $\mathrm{C} 6$ and $\mathrm{C} 12$ after propagation for over 6 months. Furthermore, since the $\mathrm{Bg} / \mathrm{ll}$ band from $\mathrm{C} 12$ migrates near the top of the gel and unlike form I or form II SV40 DNA, we conclude that the viral DNA is truly integrated in this line. The finding that the Bg/l-derived band $\mathrm{mi}$ grates faster than linear SV 40 indicates that there are no tandemly repeated copies of the genome present. We have also prepared Hirt lysates from each of these lines (after greater than 6 months' propagation) and detect no free viral DNA in any line.

We have reported previously that SV40 integration is unstable in the cells derived from one particular primary colony of SV40 transformed cells (Bender and Brockman, 1981). Indeed, two of the randomly selected lines, $\mathrm{C} 9$ and $\mathrm{C} 21$, seem to have lost an integrated copy of the viral genome during the course of these studies. It was of interest, therefore, to compare the stability of the SV 40 sequences in the nonselected lines under study here to that of SV40 DNA in the overt transformants that were selected in the parallel soft agar assay. For this purpose we propagated cells from each of six of the transformed colonies which grew in soft agar. The DNAs from each of these cell lines contained SV4O sequences after more than 3 months in culture (W.W.B., unpublished results). The stability of viral sequences in the overt transformants was further demonstrated when DNA from subclones from each of the lines was examined; the subclones retained the patterns of integration present in the primary clones. These results demonstrate that SV40 DNA is integrated in a stable configuration within the DNA of a majority of overtly transformed BALB/C-3T3 cells. In contrast, the mechanism responsible for the loss of viral sequences in four of the nonselected lines is not known. Even in these four cell lines SV40 sequences were re- tained through approximately 26 cell doublings. Loss of free viral DNA is probably not the sole explanation since, on the basis of electrophoretic mobility, the viral DNA in C9 and C21 appeared to be integrated into the cellular genome.

\section{T antigen expression}

To further characterize the nature of the integrated viral DNA and its expression in the nonselected cells, three lines, $\mathrm{C} 6, \mathrm{C} 9$, and $\mathrm{C} 12$, were analyzed in detail. C6 contains $\mathrm{T}$ antigen detectable by immunofluorescence, whereas $\mathrm{C} 9$ and $\mathrm{C} 12$ do not. T antigen expression from both $\mathrm{C} 6$ and $\mathrm{C} 12$ was detectable, however. by immunoprecipitation of $\left[{ }^{35}\right.$ S]methionine-labeled proteins using anti-T serum (Fig. 5). Small t antigen is present in both $\mathrm{C} 6$ and $\mathrm{C} 12$, but a $94-\mathrm{kDa}$ large $\mathrm{T}$ antigen is found only in C6. A new band of $33 \mathrm{kDa}$ is found in $\mathrm{C} 12$. This protein, which is apparently a truncated $\mathrm{T}$ antigen, is distinct in size from the $\mathrm{T}$ antigen found in $\mathrm{C} 6$ and that found in productively infected cells or overtly transformed cells. We do not think this is a proteolytic artifact as we do not detect this band in either wild-type transformed cells (lane M) or in C6 (lane

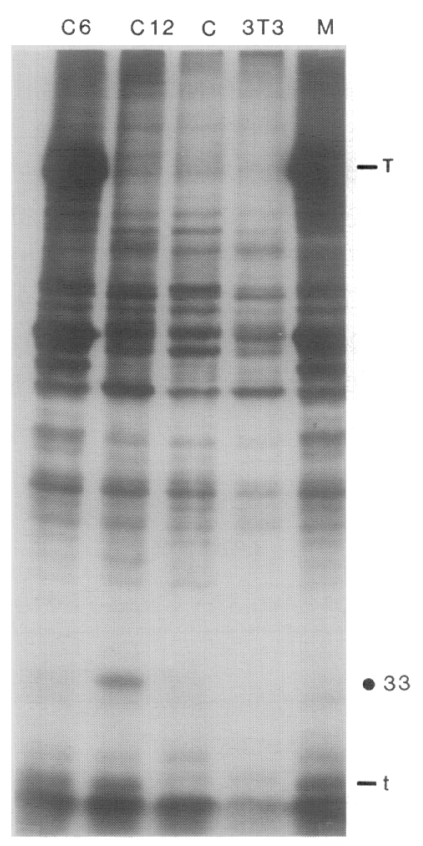

FIG. 5. Immunoprecipitation of T antigens from randomly cloned SV40 infected cells. Exponentially growing C6, C9, C12, and BALB/ c-3T3 cells were labeled with $\left[{ }^{35}\right.$ S]methionine for $2 \mathrm{hr}$ and protein extracts were prepared and analyzed by immunoprecipitation as described (Christensen and Brockman, 1982). Control lanes contain proteins immunoprecipitated from a wild-type transformed line by normal hamster serum (C) or anti- $T$ serum (M). The positions of large $\mathrm{T}$ and small $\mathrm{t}$ are indicated. The position of the $33 \mathrm{~K}$ truncated $\mathrm{T}$ antigen is also shown. 
C6) even though all samples were prepared and analyzed in parallel.

\section{Growth properties of cells}

In order to ask whether this apparently truncated $T$ was functional, we looked at the ability of the C6, C9, and $\mathrm{C} 12$ cell lines to overgrow 3T3 monolayers and form colonies in soft agar. These results are shown in Table 2. Whereas C6 is transformed in both assays, the $\mathrm{C} 9$ and $\mathrm{C} 12$ lines behave like normal cells. Thus, the truncated $T$ antigen detected in the $\mathrm{C} 12$ cells is not capable of transforming $3 \mathrm{~T} 3$ fibroblasts.

\section{Arrangement of integrated SV40 DNA in $\mathrm{C} 12$}

In order to better understand the origin of the truncated $T$ antigen, we fine mapped the integrated SV40 sequences by Southern blotting using a variety of restriction enzyme combinations. The digests of $\mathrm{C} 12$ were compared with those of SV 40 viral DNA cut with the same enzymes. If the digests of $\mathrm{C} 12$ and SV40 contained fragments of the same mobility, it was assumed that the $\mathrm{C} 12$ contained a segment of SV40 DNA colinear with the viral genome. As discussed above, digestion with $B g / l l$ yielded a single SV40-specific fragment, indicating a single integration site, and $B g / l$ yielded a band that was smaller than linear SV40, indicating no tandem integrations of viral DNA (Fig. 4). Figure 6 shows the Southern blot from the digests that most clearly define the endpoints of the integration and Fig. 7 and Table 3 summarize these data. The cumulative results of these experiments indicate that the viral sequences within $\mathrm{C} 12$ DNA must include at least those sequences extending from 0.55 to 0.14 map unit and at most sequences from 0.52 to 0.15 map unit on the SV40 genome (Fig. 7). Thus, although the late region of the genome is intact, the early transcription unit is

TABLE 2

Growth Properties of Randomly Cloned SV40-Infected Cells

\begin{tabular}{ccc}
\hline & \multicolumn{2}{c}{ Plating efficiency } \\
\cline { 2 - 3 } Cell line & $3 T 3$ monolayer $^{*}$ & Agar $^{b}$ \\
\hline 3T3 & $<0.005$ & $<0.1(<0.01)$ \\
C6 & 55 & $9.0(1)$ \\
C9 & $<0.005$ & $0.2(0.02)$ \\
C12 & $<0.005$ & $0.1(0.01)$ \\
\hline
\end{tabular}

- The ability to overgrow confluent 3T3 monolayers is expressed as (plating efficiency on monolayers/plating efficiency on plastic) $\times 100$.

- Percentage of cells plated that formed colonies in soft agar. The number in parentheses indicates the relative plating efficiency, with the value for $\mathrm{C} 6$ arbitrarily set to 1 .

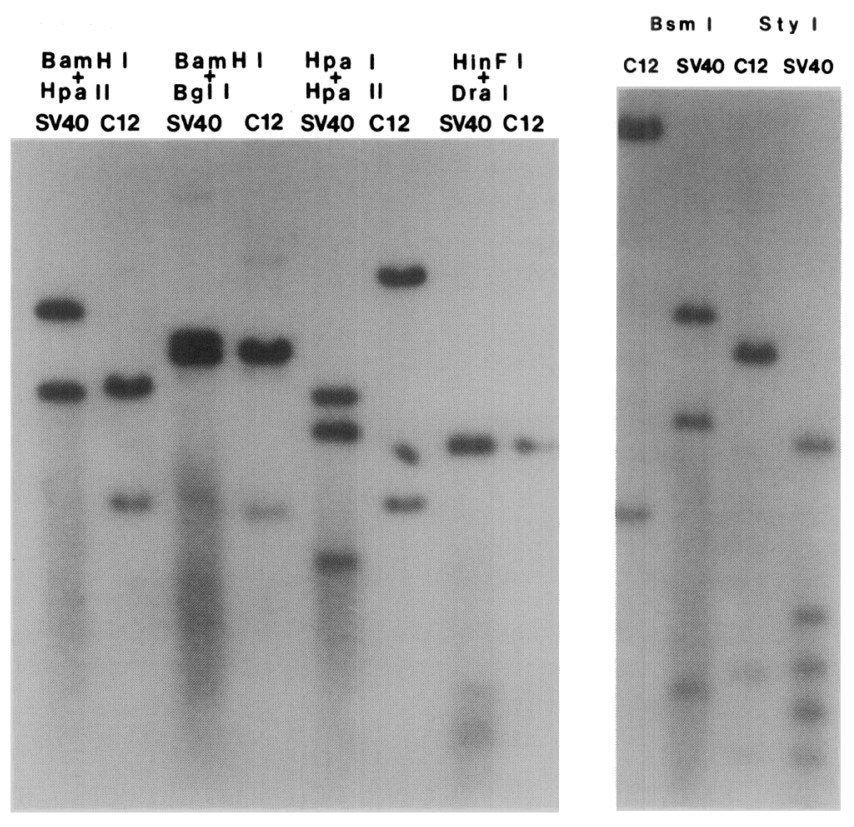

FIG. 6. Southern blot of digests used to map integrated SV40 sequences in line $\mathrm{C} 12$. DNA $(30 \mu \mathrm{g})$ was digested with the indicated enzymes and run in a $0.8 \%$ agarose gel. Next to each digest is a reconstruction in which a single copy's worth of SV40 DNA was digested with the same enzymes in the presence of $30 \mu \mathrm{g}$ normal 3T3 cell DNA. The gel was blotted and probed with the entire SV4O genome.

disrupted by recombination between viral and host sequences, resulting in the loss of most of the early region. In addition, these digests also confirm that there is no tandem integration of SV4O sequences in line $\mathrm{C} 12$.

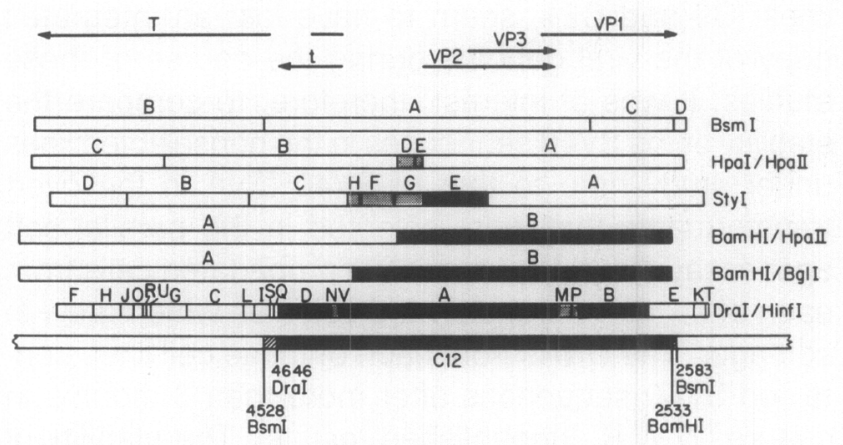

FIG. 7. Map of the integrated SV40 sequences in cell line C12. The top is a protein map of SV 40 indicating the coding sequences for the early and late viral proteins. Underneath this are diagrammed the results of the digests shown in Fig. 6 that allow us to position the ends of the integrated genome. Black boxes indicate fragments that are present in the $\mathrm{C} 12$ genome, open boxes those that are not. Stippled areas are fragments too small to be detected in the blots but which are presumably present given the results of other digests. The bottom line of the figure indicates the extent of viral sequences in clone $\mathrm{C}_{12}$. Sequences that are definitely present are drawn in solid black, and those regions that define the boundaries of the integration are hatched. 
TABLE 3

Summary of Restriction Mapping of C12 Viral Sequences

\begin{tabular}{|c|c|c|c|c|c|}
\hline \multirow[b]{2}{*}{ Enzyme } & \multicolumn{3}{|c|}{ SV40 fragments } & \multirow{2}{*}{$\begin{array}{l}\text { Presence } \\
\text { in } \mathrm{C} 12^{\circ}\end{array}$} & \multirow{2}{*}{$\begin{array}{l}\text { Other SV40-specific } \\
\text { fragments in } \mathrm{C} 12(\mathrm{~kb})\end{array}$} \\
\hline & Band & Size (bp) & (Coordinates) & & \\
\hline Bsml & $\begin{array}{l}A \\
B \\
C \\
D\end{array}$ & $\begin{array}{r}2606 \\
1846 \\
692 \\
99\end{array}$ & $\begin{array}{l}4528-1891 \\
2682-4528 \\
1891-2583 \\
2583-2682\end{array}$ & $\begin{array}{l}- \\
- \\
- \\
\text { ND }\end{array}$ & $5.0,1.3$ \\
\hline Styl & $\begin{array}{l}A \\
B \\
C \\
D \\
E \\
F \\
G \\
H\end{array}$ & $\begin{array}{r}1734 \\
945 \\
778 \\
643 \\
518 \\
296 \\
227 \\
93\end{array}$ & $\begin{array}{c}1078-2812 \\
3455-4409 \\
4409-5187 \\
2812-3455 \\
5601078 \\
37-333 \\
333-560 \\
5187-37\end{array}$ & $\begin{array}{l}- \\
- \\
- \\
- \\
+ \\
N D \\
N D \\
N D\end{array}$ & $2.3,0.8$ \\
\hline $\begin{array}{l}\text { Dral + } \\
\text { Hinfl }\end{array}$ & $\begin{array}{l}A \\
B \\
C \\
D \\
E-V\end{array}$ & $\begin{array}{r}1753 \\
565 \\
469 \\
411\end{array}$ & $\begin{array}{l}5147-1657 \\
1798-2363 \\
3907-4376 \\
4646-5057\end{array}$ & $\begin{array}{c}+ \\
+ \\
- \\
+ \\
\text { ND }\end{array}$ & \\
\hline $\begin{array}{l}\text { Hpal + } \\
\text { Hpall }\end{array}$ & $\begin{array}{l}A \\
B \\
C \\
D \\
E\end{array}$ & $\begin{array}{r}2147 \\
1856 \\
1067 \\
153 \\
20\end{array}$ & $\begin{array}{c}519-2666 \\
3733-346 \\
2666-3733 \\
346-499 \\
499-519\end{array}$ & $\begin{array}{l}- \\
- \\
- \\
N D \\
N D\end{array}$ & $3.6,1.4$ \\
\hline $\begin{array}{l}\text { Bgll + } \\
\text { BamHI }\end{array}$ & $\begin{array}{l}A \\
B\end{array}$ & $\begin{array}{l}2702 \\
2541\end{array}$ & $\begin{array}{l}2533-5235 \\
5235-2533\end{array}$ & $\overline{+}$ & 1.35 \\
\hline $\begin{array}{l}\text { Hpall + } \\
\text { Bam HI }\end{array}$ & $\begin{array}{l}A \\
B\end{array}$ & $\begin{array}{l}3056 \\
2187\end{array}$ & $\begin{array}{r}2533-346 \\
346-2533\end{array}$ & $\begin{array}{l}- \\
+\end{array}$ & 1.4 \\
\hline Mbol & $\begin{array}{l}A \\
B \\
C \\
D \\
E \\
F \\
G \\
H\end{array}$ & $\begin{array}{r}1347 \\
1264 \\
945 \\
610 \\
396 \\
384 \\
237 \\
60\end{array}$ & $\begin{array}{c}4770-874 \\
874-2138 \\
2771-3716 \\
4100-4710 \\
2138-2534 \\
3716-4100 \\
2534-2771 \\
4710-4770\end{array}$ & $\begin{array}{l}+ \\
+ \\
- \\
- \\
- \\
- \\
\text { ND } \\
\text { ND }\end{array}$ & \\
\hline
\end{tabular}

\footnotetext{
${ }^{\bullet}+$ Indicates band is present, - indicates not present. ND indicates fragment is too small to be detected on blot.
}

\section{DISCUSSION}

It is well established that the introduction of SV40 DNA into rodent cells can result in the neoplastic transformation of these cells (Topp et al., 1981). Transformation, however, occurs at a rather low frequency, $10^{-5}$ transforming units per PFU (Brockman, 1978), leading one to suspect that abortive or cryptic transformation might be occurring at a higher frequency. For example, viral sequences might integrate into the host genome in such a way that their expression is prohibited, or the host cells might differ in the expression of cellular factors with which large $T$ antigen must interact in order to transform these cells. The stability of the SV40 genome in transformed cells and revertants selected from such cells has been studied quite extensively (Steinberg et al., 1978; Bender and Brockman, 1981; Maruyama et al., 1981; Bender et al., 1981). The integrated viral genome is usually maintained stably in overtly transformed cells but is lost a good portion of the time in growth revertants.

We undertook in the present study to examine the fate of viral DNA immediately after infection of cells. We used both a totally nonselective protocol and indirect selection to introduce SV40 into murine fibroblasts. With indirect selection, we found that 57 out of 
$76 \mathrm{tk}+$ colonies were $T$ antigen positive by immunofluorescence. This frequency of coexpression is in line with previous findings (Hanahan et al., 1980). A majority of the cells that express $T$ are also transformed to some extent; one T-antigen-positive cell line is not transformed (Ryan et al., 1985). We are presently trying to determine which cellular factor(s) is responsible for this interesting phenotype.

Under totally nonselective conditions, approximately $25 \%$ of the clones contained SV40 sequences at the outset, dropping to one-third of that frequency upon subsequent passage. Thus, these cells more closely resemble transformation revertants than they do overtly transformed cells with respect to the ability to maintain viral DNA in a stable configuration. Nonetheless, the frequency of integration of SV40 DNA into cells is 10fold higher than the frequency of overt transformation under the conditions we employed. Of the two cell lines that maintained SV40 DNA, one was not transformed due to the viral DNA having integrated within the early transcription unit. Risser and Pollack (1974) have reported experiments similar to those described herein, in which they randomly cloned SV40-infected 3T3 cells and looked at T-antigen expression and transformation. They, too, found a range of transformed phenotypes and T-antigen expression, which they assayed by immunofluorescent staining. A noticeable difference between their results and the present study is that a much higher percentage of their randomly cloned cells scored as SV40 positive, $20 / 40$ as compared to $6 / 23$. This is somewhat puzzling as the m.o.i. we used was twice as high as theirs ( 4800 vs 2000 ). Although these multiplicities are still in the linear range with respect to overt transformation in our hands (Fig. 2), these authors obtain $10 \%$ overt transformation under their conditions. In addition, their frequency is based on the percentage of cells which stained positive by indirect immunofluorescence; they therefore may have underestimated the number of colonies that actually contain SV40 sequences, since we found, in one case, cells containing viral DNA even though they were T antigen-negative in the immunofluorescence assay (clone $\mathrm{C12}$ ). It is also possible that this discrepancy in frequencies is due to differences in the cell lines used by the two groups.

Our findings extend these studies in that we have examined the fate of viral DNA in the nonselected cells. Over $25 \%$ of the infected cells contained viral DNA at the outset, with two-thirds of these losing SV40 sequences upon passage. It is interesting that two of the lines which lost viral sequences gave linear genome sized bands in the Taql digests, indicating that perhaps the viral DNA never integrated and was more likely to be lost. We have also noted that even at the high multiplicity of infection we used, the SV40 DNA is present at only one to three copies per cell. Of course, we have not examined a statistically significant sample, but it may be that integration of more copies is incompatible with cell survival. Alternatively, integration may just be an inefficient event.

The exact origin of the truncated $T$ antigen in clone $\mathrm{C} 12$ is not obvious, but we think it is probably a fusion protein containing SV 40 and cellular sequences. The integration site in $\mathrm{C} 12$ has occurred within the large $T$ intron, meaning there is not enough contiguous viral coding region to account for a protein of that apparent molecular weight. Thus, the protein that immunoprecipitates from these cells is either due to aberrant splicing from the large $T$ donor site to a cellular acceptor site within the integrated chromosome or it is derived from translation through the intron and into cellular sequences. Such translation into the large $T$ intron would normally terminate at the small $t$ stop codon (nucleotide 4641), but our analysis indicates that this stop may not be present due to the site of integration. The finding that these cells are not transformed is compatible with the results of other studies on the transforming ability of mutants expressing truncated large T-antigen mutants (Pipas et al., 1983; Soprano et al., 1983). These investigators found that at least 591 of the 708 amino acids of the protein are necessary for transformation to occur.

We conclude, therefore, that integration of SV4O DNA into the host genome of nonpermissive cells occurs at a frequency that is at least 10 -fold higher than the frequency of overt transformation. There is no apparent preferred region of the viral genome at which integration occurs, as the frequency of cell lines that express large $T$ antigen roughly correlates with the fraction of the genome (one-half) that comprises the early transcription unit. In cells that contain a relatively intact early region and express large $T$, we find a range of transformation phenotypes, including one cell line that is not transformed. Our results indicate that whether or not a cell becomes transformed upon infection with SV40 depends upon the exact position of the integration event as well as the presence or absence of appropriate cellular factors required for transformation.

\section{ACKNOWLEDGMENTS}

We thank Drs. A. Boyd and G. Scangos for giving us their B2-1 cells and plasmid pTKx1, respectively. We also appreciate Drs. Mary Woodworth and Joan Rutila for their useful comments on the manuscript. This work was supported by Public Health Service Grant CA19816 from the National Cancer Institute to W.W.B. and, since his death in 1984 , to M.J.I. K.W.R. was supported during part of this work by an Institutional Training Grant from the National Institutes of Health (GM-07315). M.J.I. is the recipient of a Junior Faculty Research Award from the American Cancer Society (JFRA-120). 


\section{REFERENCES}

Bender, M. A. and Brockman, W. W. (1981). Rearrangement of integrated viral DNA sequences in mouse cells transformed by simian virus 40. J. Virol. $38,872-879$.

Bender, M. A., Christensen, J., and Brockman, W. W. (1983). Characterization of a $T$ antigen-negative revertant isolated from a mouse cell line which undergoes rearrangement of integrated simian virus 40 DNA. J. Virol. 47, 115-124.

Botchan, M., Stringer, J., Mitchison, T., and SAMBrook, J. (1980). Integration and excision of SV4O DNA from the chromosomes of a transformed cell. Cell 20, 143152.

BROCKMAN, W. W. (1978). Transformation of BALB/C-3T3 cells by tsA mutants of simian virus 40: Temperature sensitivity of the transformed phenotype and retransformation by wild-type virus. J. Virol. $25,860-870$.

Christensen, J. B., and BrockMAN, W. W. (1982). Effects of large and small $T$ antigens on DNA synthesis and cell division in simian virus 40-transformed BALB.c 3T3 cells. J. Virol. 44, 574-585.

Enouist, L. W., VANDeWoude, G. F., Wagner, M., SMiley, J. R., and SUMMERS, W. C. (1979). Construction and characterization of a recombinant plasmid encoding the gene for the thymidine kinase gene of herpes simplex type 1 virus. Gene 7, 335-342.

FeinberG, A. P., and Vogelstein, B. (1984). A technique for radiolabeling DNA restriction endonuclease fragments to high specific activity. Addendum. Anal. Biochem. 137, 266-267.

Hanahan, D., Lane, D., Lipsich, L., Wigler, M., and Botchan, M. (1980). Characteristics of an SV40-plasmid recombinant and its movement into and out of the genome of a murine cell. Cell 21, 127-139.

HIRT, B. (1967). Selective extraction of polyoma DNA from infected mouse cell cultures. J. Mol. Biol. 26, 365-369.

KETNER, G., and KFI LY, T. J., JR. (1980). Structure of integrated simian virus 40 DNA in transformed mouse cells. J. Mol. Biol. 144, 163182.

LITTLEFIELD, J. W. (1964). Selection of hybrids from matings of fibroblasts in vitro and their presumed recombinants. Science 145, 709-710.

MARUYAMA, K., HIWASA, T., and ODA, K.-I. (1981). Characterization of flat revertant cells isolated from simian virus 40 -transformed mouse and rat cells which contain multiple copies of viral genomes. J. Virol. 37, 1028-1043.

Perucho, M., Hanahan, D., and Wigler, M. (1980). Genetic and physical linkage of exogenous sequences in transformed cells. Cell 22, 309-317.

Pipas, J. M., Peden, K. W. C., and Nathans, D. (1983). Mutational analysis of simian virus $40 \mathrm{~T}$ antigen: Isolation and characterization of mutants with deletions in the T-antigen gene. Mol. Cell. Biol. 3, 203-213.

RENGER, H. C., and BASILICO, C. (1972). Mutation causing temperaturesensitive expression of cell transformation by a tumor virus. Proc. Natl. Acad. Sci. USA 69, 109-114.

RENGER, H. C., and BASILICO, C. (1973). Temperature-sensitive simian virus 40-transformed cells: Phenomena accompanying transition from the transformed to the "normal" state. J. Virol. 11, 702-708.

Rigby, P. W. J., Dieckmann, M., Rhodes, C., and Berg, P. (1977). Labeling deoxyribonucleic acid to high specific activity in vitro by nick translation with DNA polymerase I. J. Mol. Biol. 113, 237251.

RISSER, R., and POLLACK, R. (1974). A nonselective analysis of SV40 transformation of mouse 3T3 cells. Virology 59, 477-489.

Ryan, K. W., Christensen, J. B., Imptriale, M. J., and Brockman, W. W. (1985). Isolation of a simian virus $40 \mathrm{~T}$ antigen-positive, transformation-resistant cell line by indirect selection. Mol. Cell. Biol. 5, 3577-3582

Soprano, K. J., Galanti, N., Jonak, G. J., McKercher, S., Pipas, J. M., PEDEN, K. W. C., and BAserga, R. (1983). Mutational analysis of simian virus $40 \mathrm{~T}$ antigen: Stimulation of cellular DNA synthesis and activation of rRNA genes by mutants with deletions in the Tantigen gene. Mol. Cell. Biol. 3, 214-219.

SOUTHERN, E. M. (1975). Detection of specific sequences among DNA fragments separated by gel electrophoresis. J. Mol. Biol. 98, 503517.

Steinberg, B., Pollack, R., Topp, W., and Botchan, M. (1978). Isolation and characterization of $T$ antigen-negative revertants from a line of transformed rat cells containing one copy of the SV40 genome. Cell 13, 19-32.

TOPP, W. C., LANE, D., and POLLACK, R. (1981). Transformation by SV40 and Polyoma virus. In "DNA Tumor Viruses: Molecular Biology of Tumor Viruses" (J. Tooze, Ed.), 2nd ed. rev., pp. 205296. Cold Spring Harbor Laboratory, Cold Spring Harbor, NY. 